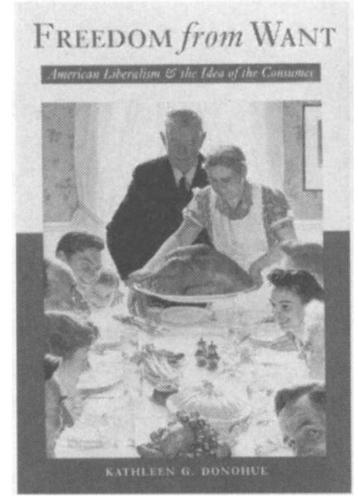

New Studies in

American Intellectual and Cultural History

Howard Brick, Series Editor

\section{Freedom from}

\section{Want}

American Liberalism and the Idea of the Consumer Kathleen G. Donohue

"An important contribution to the history of modern

American liberalism. In a series of exceptionally acute readings of writers and activists both familiar and obscure, she makes a compelling case for an important shift in the estimate of the virtues of the consumer in American economic thought from the mid-nineteenth century through the New Deal."

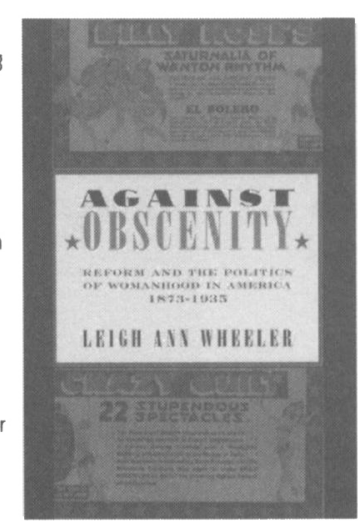
-Robert Westbrook, University of Rochester $\$ 45.95$ hardcover

\section{The Big Vote} 1890s-1920s

\section{Liette Gidlow}

$\$ 45.00$ hardcover

\section{Political history}

\section{Reconfiguring American Political History}

Ronald P. Formisano, Paul Bourke, Donald DeBats, and Paula M. Baker, Series Founders

Gender, Consumer Culture, and the Politics of Exclusion,

"Liette Gidlow illuminates not only the strategic and structural facets of the 'Get Out the Vote' campaigns of the 1920 s but also the ways in which women and men, black and white, and in various regions of the country, pursued places for

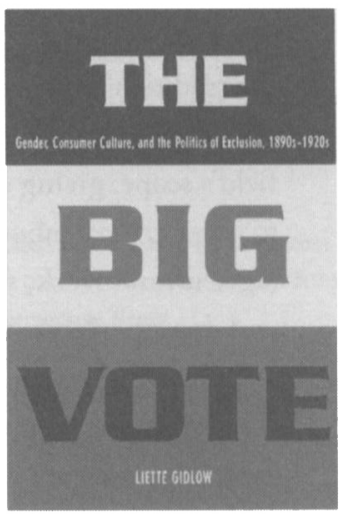
themselves in the public sphere.

Highly readable, this book provides important insights for all scholars interested in the creation of the political past and how that past influences our political culture today." - Melanie Gustafson, University of Vermont

\section{Against Obscenity}

Reform and the Politics of

Womanhood in America, 1873-1935

\section{Leigh Ann Wheeler}

"Rather than portraying early twentiethcentury debates over obscenity as a part of a continuous battle between the forces of 'repression' and 'enlightenment,' Leigh Ann Wheeler identifies key moments in these early sex wars, skillfully elucidating the changing significance of gender." -Wendy Gamber, Indiana University $\$ 44.95$ hardcover

The Johns Hopkins University Press • 1-800-537-5487 • www.press.jhu.edu 


\section{LABOR \\ Studies in Working-Class History of the Americas}

\section{The mission of Labor}

While still paying critical homage to the tradition from which the journal derives its energy, Labor expands the field's scope, giving equal attention to other critical labor systems (agricultural work, slavery, unpaid and domestic labor, the informal sector, the professions, etc.) and social contexts (race, gender, class, ethnicity, etc.). The journal's focus, beginning with U.S. experience, extends to developments across the "American" hemisphere and incorporates transnational comparisons that shed light on the American experience.

\section{Don't miss this special issue}

"Class Analysis in Early America and the Atlantic World: Foundations and Futures" offers a reevaluation of the potential and future of class analysis in scholarly work, particularly as it relates to increasing the understanding of the popular struggle in the early modern Atlantic world, a struggle that lies at the heart of many of today's class-related dilemmas.

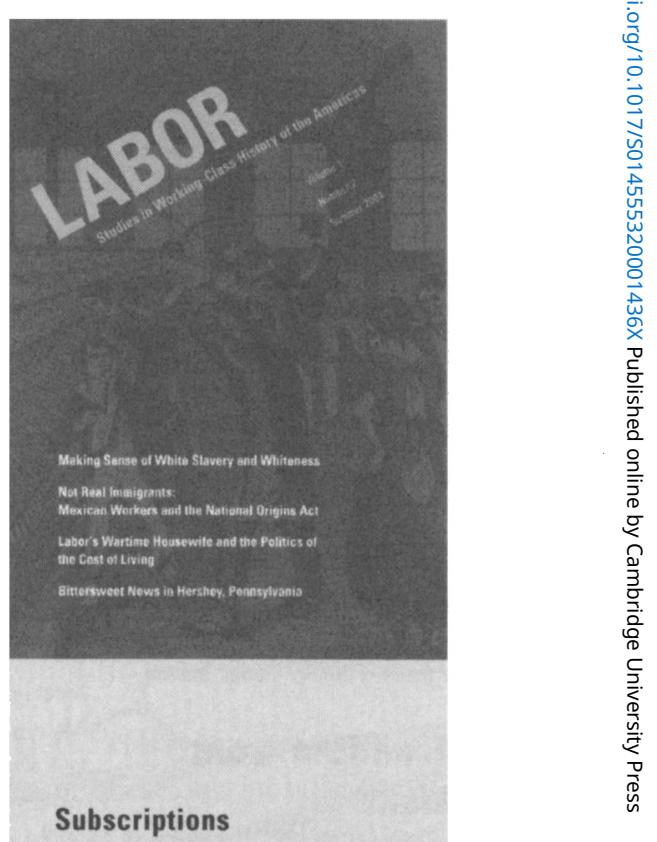

Individual subscription, $\$ 40$

Student subscription, $\$ 25$

(photocopy of

current ID required)

For more information,

please visit our Web site:

www.dukeupress.edu/labor

or call toll-free 888-651-0122

(within the U.S. and Canada)

or 919-687-3602. 
World Wide Web Visit Duke University Press Journals at www.dukeupress.edu/journals.

Subscriptions Direct all orders to Duke University Press, Journals Fulfillment, 905 W. Main St., Suite 18B, Durham, NC 27701. Annual subscription rates: institutions, \$95; e-only institutions, $\$ 86$; individuals, $\$ 60$; students, $\$ 15$. Add $\$ 12$ postage and $7 \%$ GST for Canada. Add $\$ 16$ postage outside the U.S. and Canada. Individual and student subscriptions include membership in the Social Science History Association. Back volumes (institutions): \$95. Single issues: institutions, $\$ 24$; individuals, $\$ 15$. For more information, contact Duke University Press Journals at 888-651-0122 (toll-free in the U.S. and Canada) or 919-687-3602; subscriptions@dukeupress.edu.

SSHA Membership Address membership inquiries to Erik Austin, ISR, University of Michigan, 426 Thompson St., Ann Arbor, MI 48106-1248.

Photocopying Photocopies for course or research use that are supplied to the end user at no cost may be made without explicit permission or fee. Photocopies that are provided to the end user for a fee may not be made without payment of permission fees to Duke University Press.

Permissions Address requests for permission to republish copyrighted material to Permissions Coordinator, Duke University Press, 905 W. Main St, Suite 18B, Durham, NC 27701; permissions@dukeupress.edu.

Advertisements Direct inquiries about advertising to Journals Advertising Specialist, Duke University Press, 905 W. Main St., Suite 18B, Durham, NC 27701; journals_advertising@dukeupress.edu.

Social Science History is indexed and abstracted in America: History and Life, American Bibliography of Slavic and East European Studies, Applied Social Science Index and Abstracts, Arts and Humanities Citation Index, ASCA, Current Contents, Historical Abstracts, Language and Language Behavior Abstracts, Sage Public Administration Abstracts, Sage Urban Studies Abstracts, Social Sciences Citation Index, Studies on Women Abstracts, and United States Political Science Documents.

Copyright $(\mathbb{C} 2004$ by the Social Science History Association ISSN 0145-5532 
Jeffery A. Jenkins, Eric Schickler, and Jamie L. Carson Constituency Cleavages and Congressional Parties: Measuring Homogeneity and Polarization, 1857-1913

\section{Matthias Gross}

Human Geography and Ecological Sociology: The Unfolding of a Human Ecology, 1890 to 1930 -and Beyond

Pieter Spierenburg

Punishment, Power, and History: Foucault and Elias

Lewis H. Siegelbaum

The Condition of Labor in Post-Soviet Russia:

A Ten-Year Retrospective

Larry Sawers

The Mule, the South, and Economic Progress 